\title{
Internationalization, Legalization and Deterrence: The United States and Japan in the South China Sea*
}

\author{
JEFFREY ORDANIEL ${ }^{* *}$
}

Lately, China's assertiveness in the South China Sea has unsettled Southeast Asia. Beijing's aggressive efforts to press its claim over $80 \%$ of the South China Sea have worried ASEAN. However, non-claimants have expressed interests in a peaceful resolution. Why is the United States so passionately involved? And why is Tokyo too worried? First, this paper traces the origins of the interests and threat perception of the U.S. and Japan towards the South China Sea. Second, this paper asserts that emerging strategies revolve around three concepts: internationalization, legalization and deterrence, which can be categorized as either soft or hard balancing. Finally, this paper argues that the U.S. and Japan employ both types of balancing against threats to their interests as complements.

Keywords: Balancing, South China Sea, Maritime Security, China, Southeast Asia, Japan, United States

* This paper was presented at the 2015 Annual Conference of the Association for Asian Studies (AAS), Chicago, Illinois, USA, March 26-29, 2015.

** Ph.D. Candidate, Security and International Studies Program, National Graduate Institute for Policy Studies, Tokyo, Japan;

E-mail: doc13114@grips.ac.jp

DOI: 10.16934/isr.16.2.201512.93 


\section{INTRODUCTION}

The South China Sea issue is one of the most consequential traditional security challenges facing East Asia. The overlapping claims to territories and maritime entitlements in the South China Sea are complex, highly contentious and sensitive. The disputes involve a rising great power that is China, an emerging Vietnam and a reinvigorated U.S. treaty-ally, the Philippines. Other littoral states-Malaysia, Brunei, Taiwan and even Indonesia-also have direct stakes in the ultimate resolution of the disputes that involve not just questions of sovereignty but also concerns over international maritime order.

Some research on the South China Sea paints the issue as mainly a struggle between the status-quo power that is the U.S. and the rising power that is China, intersecting with the aspirations of smaller, emerging regional states (e.g. Kaplan 2014; Le Mière and Raine 2013). Other research discusses the disputes involved under a Liberal lens by exploring past, current and future possible opportunities for interstate cooperation (e.g. Buszynski and Sazlan 2007; Hong 2012), with some even moving further by proposing concrete solutions considering the legal, political and military dynamics at play (e.g. Valencia et al. 1999). This paper attempts to add another layer to the discussions by focusing on two important actors in the South China Sea, albeit non-claimants-the U.S. and Japan.

In recent years, these two non-claimant states to the South China Sea disputes have been particularly vocal in expressing their interests in the issue. They have been emphasizing the peaceful resolution of maritime and territorial disputes, and adherence to the rule of law. They have also been strengthening their engagements with maritime Southeast Asia, much to the discomfort of China. All these raise important questions - how does Beijing's South China Sea claim threaten Washington? And why is Tokyo also worried? How are the two allies balancing China in the South China Sea?

China's recent attempts to project power in, and dominate, the South China Sea, and the apparent resistance from Japan and the U.S., provide an opportunity to reveal exactly how, when, and under what circumstances do contemporary great powers choose to balance, as well as the instruments through which they do so. First, this paper traces the origins of the expressed interests and threat perception of the U.S. and Japan towards the South China Sea issue. Second, this paper asserts that their recently emerging strategies as determined by their interests and changing threat perception revolve around three concepts: internationalization, legalization and deterrence. Each of these can be categorized as either soft or hard balancing. Finally, this paper argues that the U.S. and Japan employ both types of balancing against threats to their South China Sea interests simultaneously. Apparently, Washington and Tokyo perceive soft and hard balancing as complementary. Overall, this paper adopts the view that the U.S. and Japan's balancing acts in the 
South China Sea are mostly motivated by self-interests and perceived threats concerning economic security and geopolitical considerations, pursuant to Realist predictions.

\section{HARD-BALANCING AND SOFT-BALANCING IN INTERNATIONAL RELATIONS}

Traditional balance-of-power theory would suggest that the U.S. and Japan should be hard-balancing China to protect their South China Sea interests. These should be in the form of their military buildup and overall capability upgrade and/ or external balancing, which mainly refers to alliance or coalition building. Indeed, all of these have been done by both powers in order to deter China from furthering its South China Sea claims. But apart from hard-balancing, what is also remarkable is their employment of soft-balancing, namely internationalization and legalization to preserve their interests in the South China Sea. These have not been discussed in the literature.

In contrast to hard balancing, soft balancing is a relatively new idea. Robert Pape (2005) introduced the concept when he described how other major powers employed measures that do not directly challenge the military superiority of the U.S. but used "international institutions, economic statecraft and diplomatic arrangements to delay, frustrate, and undermine U.S. policies" particularly on the unilateral use of force or intervention. What he is arguing is that, soft balancing is undertaken "not to physically balance a stronger state but for weaker states to undermine, frustrate and increase the cost of unilateral action on the part of the stronger state." Ilai Saltzman $(2012,133)$ further argued that the end goal of softbalancing is to "increase states' security by restraining the emerging power and discouraging it from carrying out its over-reaching hegemonic aspiration rather than creating countervailing alliances or initiating arms races." Meanwhile, T.V. Paul $(2005,59)$ asserted that "in the post-Cold War era, soft balancing has become an attractive strategy through which second-tier major powers are able to challenge the legitimacy of the interventionist policies of the United States and its allies both internationally and in U.S. domestic public opinion."

However, these arguments seem to draw a line that makes hard and soft balancing mutually exclusive. In other words, existing literature that looks at the relationship between soft and hard balancing as foreign policy or security strategy choices assumes that states treat hard and soft balancing as substitutes or alternatives to each other. Moreover, they also mostly discuss soft-balancing as a strategy of a militarily inferior state against a superior state.

This paper argues that both Washington and Tokyo have been employing both soft and hard balancing simultaneously against threats in the South China Sea. The two powers regard both types of balancing as complementary in securing their 
interests in the South China Sea. This paper also demonstrates that soft balancing is not exclusive to militarily inferior states balancing against superior states as shown by how the U.S. is employing the strategy to complement its hard-balancing efforts against China in the South China Sea.

For this paper, two soft-balancing concepts are introduced: internationalizetion and legalization. In this paper, internationalization refers to any efforts by a state to: 1) connect an issue to wider international concerns; 2) bring an issue to multilateral discussions; and 3) put an issue in its bilateral agenda with other states not directly involved. Legalization refers to efforts of a state to: 1) attempt to establish legal, quasi-legal governance mechanism with other states to govern state behaviors on a particular issue or set of issues, or encourage others to do so; and 2) link an issue to existing international laws, norms or legal institutions.

Meanwhile, the deterrence concept is used in this paper to mainly refer to hard balancing as it is broadly defined by the Balance of Power theory-military build-up and alliance/coalition building.

\section{CHINA'S CLAIM AND WHAT IT COULD MEAN FOR MARITIME EAST ASIA}

The security tensions in the South China Sea revolve around China's expansive "indisputable sovereignty" claim over the vast body of water, as expressed in its nine-dash line map, and in Beijing's perceived assertiveness in enforcing that claim. First, any discussion of the disputes must work under the premise that China's claim over almost $80 \%$ of the South China Sea is ambiguous. It has no specific geographic coordinates and Beijing has continually refused to clarify it. Second, much of China's arguments centers on history. How China interprets the history of the South China Sea forms part of the basis of the claim. China's historical assertions however are not without questions. Southeast Asian and Western scholars have argued that China's historical claims over the South China Sea are weak (e.g. Hayton 2014, 24-28; Bonnet 2012), if not concocted. Other arguments against China's historical claim involve old Chinese government documents, such as the country's previous constitutions that have pointed to Hainan Island as the southernmost territory of China. These things and Beijing's ambiguous basis on international law for its nine-dashed line map give Southeast Asian countries an impression that the current Chinese claim is irredentist and outright expansionist. As a case in point, taking the UN General Assembly Podium on September 29, 2014, Philippine Foreign Secretary Albert Del Rosario said, "We have invited a State Party to settle our maritime disputes peacefully through UNCLOS (UN Convention on the Law of the Sea) including its provisions on dispute settlement, specifically arbitration. However, it has refused to join us and has continued to unilaterally embark on an expansionist claim that violates the 
legitimate rights of the Philippines and other littoral neighbors under UNCLOS such as their Exclusive Economic Zones and Continental Shelves" (UN News Centre 2014).

For direct claimants like Manila and Hanoi, caving in to Chinese demands and pressures would mean that, on top of losing sovereignty over disputed land features that they currently occupy, they would also consequentially lose most of their UNCLOS entitlements. These include significant reduction of their territorial waters, contiguous zones, exclusive economic zones (EEZ), and continental shelves in the South China Sea generated from their undisputed main landmass. Lost entitlements would include the fishery resources in those waters and the oil and gas that could be beneath the seabed. Hence, Southeast Asian claimant states' primary interests in the South China Sea are twofold-to keep their maritime entitlements in the South China Sea as defined by the Law of the Sea Convention, and to maintain the status quo, namely their hold on several land features and their control and exploitation of resources in the surrounding waters.

For the rest of maritime East Asia, the Chinese claim as it currently stands could undermine the existing global order. In particular, China's emphasis on "respecting historical facts" could mean that Beijing's own historical interpretations should take precedence over established international maritime norms. The Chinese claim could give Beijing the right to control or regulate the passage of ships considering that China's 1992 Law of Territorial Sea contain provisions on hot pursuit, among other contentious wording (Kim 1994).

Moreover, the ambiguity of what the dotted lines represent and how they correspond to UNCLOS on maritime demarcations and entitlements bring risks of accidental clashes brought about by overlapping law-enforcement patrols, power projection exercises and potentially regional sea-lane of communication (SLOC) controls and regulations. The ambiguity could also breed mistrust in the region.

\section{EXPLAINING THE SHIFT IN AMERICAN AND JAPANESE PERCEPTIONS}

In the past couple of years, China has been increasingly perceived by Southeast Asian countries and even by the U.S. and Japan, to be using intimidation and coercion to change the status quo, gradually. Pundits, scholars and policymakers have described this strategy as "salami-slicing" or a strategy that requires a sequence of many actions overtime to achieve a goal (Haddick 2012). The accumulated advantage overtime would have been difficult or unlawful, if not impossible to gain all at once by a single, larger action. Indeed, there have been many confrontations in the South China Sea since 1974. Scholar Brad Kaplan (2013), who used data compiled by the Center for New American Security, discovered that in $80 \%$ of the 30 confrontations identified as significant or high-level, China was involved; followed by the Philippines and Vietnam, each involved in $40 \%$ of the 
tensions. In some of the confrontations, control over a disputed feature was reversed in favor of Beijing, such as the Fiery Cross Reef skirmish in 1988; the Mischief Reef incident in 1995; and the Scarborough Shoal standoff in 2012, among others.

The long list of confrontations since 1974 indicates that Beijing's current maneuvers in the South China Sea, with the exception of the massive and simultaneous land-reclamation activities on reefs already under its control, are not necessarily new. However, it must be noted that tensions that occurred prior to 2008 have not received much attention from both Washington and Tokyo. For instance, when the Chinese occupied the Mischief Reef in 1995, Washington was not as worried. Even when the Chinese converted its stilt-based outpost on the same reef into a concrete military garrison with helipad and surveillance-communication equipment in the late 1990s despite previous promises from Beijing that the initial structure was merely for providing shelter for distressed Chinese fishermen, the U.S. remained less interested and largely unalarmed. Moreover, although its treaty ally was at a disadvantage, the U.S. was reticent to the idea of coming to the aid of the Philippines (Storey 1999) and it remained in the sidelines.

Moreover, prior to 2009, the U.S. was not as concerned about freedom of navigation, unimpeded commerce and access to global commons becoming threatened by the disputes in the South China Sea as it is today. China, despite being involved in $80 \%$ of the confrontations through the years, apparently was not yet seen by Washington to be a threat to those interests. For Tokyo, its focus had always been on the Malacca Strait where piracy and other illicit activities could threaten Japanese vessels' freedom of navigation and trade (Sato 2007). Throughout the 2000s, the South China Sea disputes were not a top-of-mind concern for Tokyo.

However, since 2009, there has been a noticeable shift in American and Japanese perception of the South China Sea issue, which this paper asserts was partly due to the relative increase of perceived Chinese assertiveness and the significant rise in the status of China as an emerging great power. The launch of the U.S. "pivot to Asia," which was later renamed "rebalance to Asia" served as a prelude and the overarching framework to Washington's greater attention to the South China Sea issue.

By the summer of 2010, during an ASEAN meeting, U.S. Secretary of State Hillary Clinton for the first time had declared Washington's national interest in the South China Sea disputes. Clinton underscored freedom of navigation and unimpeded lawful commerce, and directly attached them to the disputes over the South China Sea. It was the beginning of Washington's efforts to propagate the narrative that the South China Sea disputes concern freedom of navigation, among other global concerns.

By 2011, clearly with the South China Sea in mind, Washington re-emphasized its treaty commitments with Manila, while sealing a deal with Canberra on increased 
U.S. troop presence in northern Australia. During the 2012 Scarborough Shoal Standoff between Chinese and Filipino vessels, American intervention was instrumental in its ultimate de-escalation (Dyer and Sevastopulo 2014). Then-Asst. Secretary of State for East Asia and Pacific Affairs Kurt Campbell was deeply involved in finding a face-saving solution to the confrontation. Such was a clear indication that unlike during the 1995 Mischief reef incident, the South China Sea was, at this time, already front and center in the U.S. Pacific security interest. Likewise, Campbell's successor Daniel Russel was in Hanoi at the height of the 2014 oil-rig crisis that occurred when Beijing's national oil company moved its oil-rig operations in the waters also claimed by Vietnam (Chu 2014). Russel, along with other top ranking American officials in Washington was seen as actively advising Hanoi and criticizing Beijing for its "provocation."

The U.S. was also among the first countries to criticize Hainan Province's new fishing regulation in January 2014. The regulation, in principle covers more than two million square kilometers or more than $50 \%$ of the whole South China Sea, presumably including the high seas within the U-shaped nine-dash line (Fravel 2014).

The U.S. also attempted to halt China's land-reclamation of disputed reefs and low-tide elevations that started in 2014 by proposing a moratorium (Fuchs 2014). It was a futile attempt however, as China successfully completed all its reclamation projects by the autumn of 2015. Nevertheless, it corroborates the claim that, unlike in the past, Washington is now adamant to frustrate Beijing's South China Sea plans through legal and diplomatic arrangements in order to safeguard its own interests.

In almost all of these, Japan was with the U.S., adding its voice to the growing criticism of China's South China Sea policies and behaviors. It must be noted that Japan has also been experiencing its own share of Chinese assertiveness in the East China Sea.

What made the difference? For all these, it is becoming clearer that the concerns of the U.S. and Japan are dependent on both Chinese behavior and the perception of China as a rising or risen power. Indeed, it was only in 2010 that China became a larger economy than Japan. Confrontations involving China alone were insufficient in warranting American and Japanese attentions, such as those prior to 2009 as these were not yet perceived as too threatening for Washington and Tokyo. The recent behaviors being displayed by a much more powerful China are providing Washington and Tokyo greater worries on the future of the East Asian order in general and their economic and geopolitical interests in the South China Sea in particular. In other words, the increasing Chinese assertiveness coupled with the status of China as a formidable rising or risen power are warranting balancing from the status-quo powers. But what exactly are their South China Sea interests? 


\section{AMERICAN AND JAPANESE INTERESTS IN THE SOUTH CHINA SEA}

First, it has been a constant refrain that the South China Sea is a very important sea-lane. Through the Malacca Strait, the sea provides the shortest, most costeffective route for commercial vessels transiting between Northeast Asia and the countries in the Middle East, the Indian Ocean and Southeast Asia. It is where more than half of the world's oil tankers and where more than five trillion USD of world trade (or more than half of the world's total merchant fleet by tonnage) pass through (Rosenberg 2014, 7). Hence, discussions on the South China Sea most often involve international commerce and freedom of navigation concerns, in addition to the fact that portions of the South China Sea inside China's u-shaped nine-dash lines, have long been considered parts of the global commons. Second, there is a concern that China is a hegemon-in-waiting. Its nine-dash line map could be used to advance Beijing's possible plan to dominate the region's affairs by being in full control of an important trade route and choke point. Some scholars (e.g. Mearsheimer 2014) argue that China is attempting to dominate its own region in the same way that the U.S. and previous world powers attempted to dominate theirs.

Given these considerations, the interests of the U.S. and Japan are primarily rooted on two concerns-economic security and geopolitics.

\section{United States}

For the U.S., its interests mainly concern freedom of navigation and overflight, unimpeded lawful commerce, and access to global commons, including military surveillance in EEZs and innocent passage in any countries' territorial waters, as well as the moderation, if not containment of China's rise as an East Asian hegemon. These, with the exception of the last one, have been constantly articulated by top American officials beginning in July 2010 when former Secretary of State Clinton announced during that year's ASEAN Regional Forum in Hanoi that the peaceful resolution of the South China Sea disputes is in the U.S. "national interests" (U.S. Department of State 2010) as duly noted above.

\section{(1) Freedom of Navigation}

Washington's security and economic interests underpin its freedom of navigation concern in the South China Sea. First, from a security standpoint, the U.S. wants to ensure the freedom of movement of all its military assets in the Indo-Pacific Region. In particular, the South China Sea is a critical route for American naval vessels operating in Western Pacific, primarily based in its bases 
in Japan, reaching into the Indian Ocean and the Middle East. For decades, American carriers, destroyers, frigates, submarines, and other assets traverse the water with no restrictions, which proved to be crucial during crisis periods in the Middle East.

Furthermore, it is no secret that Washington and Beijing hold divergent views on related international law. China has long been complaining of military surveillance by U.S. vessels and aircraft in its EEZ (Manicom 2014). The first high-level tension on this matter occurred on April 1 $1^{\text {st }}, 2001$ when an American Navy EP-3E ARIES II signals intelligence aircraft and a People's Liberation Army Navy (PLAN) J-8II interceptor fighter jet had a mid-air collision in the airspace of Hainan Island's EEZ (Zhang 2001). China believes that it has the sovereign right to regulate foreign military activities in its EEZ, which could be prejudicial to its own security. The U.S. has maintained that "sovereign rights" to EEZs beyond the territorial sea only refers to the exclusive right to exploit the living and non-living resources within the specified maritime domain, excluding other sovereign rights such as the right to regulate or limit freedom of navigation and over-flight, and deny passage of military vessels and aircrafts. Moreover, China is also demanding prior notification before any military vessels could enter its territorial waters, including the surrounding waters of its artificial islands in the Spratlys. The U.S. insists on "innocent passage" as allowed by customary international law and UNCLOS. These opposing interpretations of related international law continue to be a thorny issue between the two governments. These legal disagreements were further highlighted by the March 8, 2009 incident, in which three Chinese government vessels, one owned by its navy and two by its civilian maritime law enforcement agency, with two smaller private fishing trawlers, surrounded and harassed the USNS Impeccable approximately 75 miles south of Hainan Island in the South China Sea. "The fishing trawlers maneuvered within 25 feet of Impeccable and then intentionally stopped in front of it, forcing Impeccable to take emergency action to avoid a collision" (Pedrozo 2009, 101). The recent controversies on China's claimed "military alert zone" around the reclaimed features in the Spratlys reconfirm that the conflicting views on maritime entitlements, among other issues remain a struggle between the two Pacific powers.

Moreover, from an economic standpoint, the South China Sea is an important sea-lane for the U.S. As noted above, around half of the world's oil tankers, most of them travel to and from U.S. allies in East Asia, traverse the disputed waters. Also, of the estimated five trillion dollars of annual trade that pass through the disputed waters, 1.2 trillion dollars of which is U.S. trade (Xu 2014). Any military conflict in the South China Sea could disrupt the free flow of commercial vessels. Also, portions of the South China Sea have long been considered part of the global commons or the high seas. The U.S. is opposed to any effort to turn the vast body of water into either territorial sea or an EEZ of a single country. China's U-shaped 
nine-dash line map could provide Beijing the justification to begin regulating the passage of vessels.

The U.S. commitment to freedom of navigation and open access to global commons have long been the highlight of its foreign policy on maritime security, even during the Cold War, and thus pushing back against China's expansive, seemingly arbitrary claim in the South China Sea must be expected from Washington. For instance, the U.S. Government's Freedom of Navigation (FON) Program, in existence since the 1970s, is a testament to this. The U.S. State Department describes the FON Program as operating "on a triple track, involving not only diplomatic representations and operational assertions by U.S. military units, but also bilateral and multilateral consultations with other governments in an effort to promote maritime stability and consistency with international law, stressing the need for and obligation of all States to adhere to the customary international law rules and practices reflected in the LOS Convention" (US Department of State, n.d.). By highlighting freedom of navigation, Washington is in turn strengthening the narrative that the South China Sea does not belong to Beijing and the passage of vessels, military or commercial, should not be impeded, controlled or regulated by any single state.

\section{(2) Geopolitical Considerations}

Politically, the U.S. is cautious of the implications of China's regional dominance. Realists would argue that the American push back against China's sweeping South China Sea claim is expected as their theory suggests that statusquo power from one region of the world is likely to curtail the hegemonic rise of another great power in another part of the world. Beijing's ambiguous claim is particularly worrisome for Washington because it could mean that China is bent on constructing a new regional maritime order that could possibly displace the preeminence of the U.S. in Asia-Pacific. The U.S. wants China to get on board and strengthen, not weaken, existing international institutions built under American leadership. This could explain why the U.S. has been, in recent years stressing the importance of adhering to international law in managing the disputes in the South China Sea. Washington's emphasis on the rule of law should not be taken as benevolence but rather as a balancing act in order to restrain China and its ambitions to dominate the region. Recognition of Chinese claims in the South China Sea could weaken international law on maritime entitlements and could reduce American geopolitical influence in East Asia.

\section{Japan}

For Japan, its interests in the South China Sea revolve around three factors: 
the maintenance of freedom of navigation and unimpeded commerce; respect for international law; and the link between the East China Sea and the South China Sea disputes.

\section{(1) Freedom of Navigation, Over-flight and Commerce}

Freedom of navigation and overflight, and unimpeded commerce are at the center of Tokyo's interests in the South China Sea. Using data from Japan External Trade Organization (2014), Japan's annual two-way trade in goods with ASEAN amounted to more than US\$230.3 billion, with South Asia, US\$ 20 billion, with the Middle East, US\$ 187.5 billion and with Europe, US\$ 168.3 billion or a combined $32 \%$ and $45 \%$ of the country's total exports and imports, respectively in 2013. The shortest, most cost-effective way to reach the countries of those regions from the Japanese islands is through the South China Sea and the Malacca Strait. Apart from trade in goods, most of the country's energy needs, supplied through tankers, originating from the Middle East, are passing through the South China Sea before reaching Japan. For instance, 2013 statistics from Japan's Ministry of Internal Affairs and Communication (2014) shows that, of the country's 210.3 million kiloliters of total crude oil imports that year, 84\% were sourced from the Middle East and 5\% from Southeast Asia. Those statistics clearly show a link between the South China Sea and Japan's medium to long term energy security and economic stability. As Asia's second largest trading nation, it would be detrimental for Tokyo if the entire South China Sea falls under the complete control of Beijing.

Tokyo has a recent experience of how its economic vulnerability was exploited by China for political gains. It must be noted that in September 2010, in order to pressure Tokyo to release the Chinese captain who deliberately rammed his ship on Japanese Coast Guard vessels, China suspended the export of rare-earth minerals to Japan (Bradsher 2010). Rare-earth minerals are vital for Japan's electronic industry and China at that time, held $97 \%$ of supply. Acquiescing to China's version of maritime order in the South China Sea could mean providing Beijing yet another lever (e.g. implementing selective blockade) through which it could coerce other countries, including Japan. American Scholar Alexander L. Vuving (2014) noted, "If China dominates this chokepoint, it will be able to switch off at will about 60 percent of Japan's energy supplies."

Moreover, Tokyo's interest in safeguarding freedom of navigation and the safety of critical sea-lanes is nothing new (Storey 2013). Given Japan's geographic position, the country has always been sensitive to issues involving the regional maritime order, particularly to the sources of threats. For instance, in 1968 Japan was instrumental in the establishment of the Malacca Strait Council (MSC). Funded 
by the Japanese Government, the MSC "financed the purchase, installation and maintenance of navigational aids such as buoys, light beacons, lighthouses and a traffic separation scheme" (Vertzberger 1984, 9). Storey $(2013,139)$ noted that "Japan's support for the MSC was designed to enhance the country's economic security" and was, thus, far from being altruistic. In the 1990s and early 2000s when piracy became a threat to Japanese vessels, Tokyo endeavored to establish multilateral arrangements to address the problem, and moreover provided substantial aid to Southeast Asian littoral states so they could improve their law-enforcement and monitoring capacities. Since then, Japan had been investing a significant sum to increase the maritime security capabilities of Southeast Asian littoral states, particularly of those directly facing the Malacca Strait and the South China Sea.

\section{(2) Respect for International Law}

Apart from making sure that international sea-lanes are not disrupted, there are two other rationales why Japan is adamant at preserving regional order and why it has an interest in China's adherence to the rule of law in the South China Sea. One is its alliance with the U.S. and another is its own interest of preventing the rise of a regional hegemon. First, being an ally of the U.S., Japan is expected to support the stance of Washington in matters of security. The U.S. has a nonnegotiable position on adherence to international law in the area of maritime security, particularly on freedom of navigation. Any conflict in the South China Sea that involves the U.S., resulting from China's possible violation of international law, could ultimately drag Japan per U.S.-Japan defense pact, directly or indirectly. Logistical support and collaboration in intelligence, surveillance and reconnaissance are highly likely to be asked at peacetime. Should any conflict in the South China Sea that involve the U.S. escalate, the 2015 Guidelines for Japan- U.S. Defense Cooperation mandates:

"The two governments will cooperate closely to enhance maritime security. Cooperative measures may include, but are not limited to, information sharing and inspection of ships based on a United Nations Security Council resolution or other basis under international law .... When Japan and the United States each decides to take actions involving the use of force in accordance with international law, including full respect for sovereignty, and with their respective Constitutions and laws to respond to an armed attack against the United States or a third country, and Japan has not come under armed attack, they will cooperate closely to respond to the armed attack and to deter further attacks. Bilateral responses will be coordinated through the whole-of-government Alliance Coordination Mechanism. Japan and the United States will cooperate as appropriate with other countries taking action in 
response to the armed attack. The Self-Defense Forces will conduct appropriate operations involving the use of force to respond to situations where an armed attack against a foreign country that is in a close relationship with Japan occurs and as a result, threatens Japan's survival and poses a clear danger to overturn fundamentally its people's right to life, liberty, and pursuit of happiness, to ensure Japan's survival, and to protect its people" (Ministry of Foreign Affairs of Japan 2015).

This does not necessarily mean that Japan fears entanglement. However, considering the sensitivities of the Japanese polity to Self-Defense Forces' (SDF) involvements in overseas conflicts, Tokyo's political leaders certainly do not want to be put in such uncomfortable situation.

Second, it is in the interest of Tokyo to prevent the rise of a regional hegemon. Preserving the current maritime order means the preponderance of the U.S. in Asia-Pacific. It is inevitable that any use of force by China against Southeast Asian countries would result in Chinese dominance of the South China Sea, and of the region at large, which does not suit Japan's overall geopolitical and security interests. Simply put, for Japan, respect for international law means the continued supremacy of the U.S. in East Asian affairs and the containment of China's regional hegemonic ambitions.

\section{(3) Link between the East and South China Seas}

Finally, Tokyo views the disputes in the South China Sea as issues not totally separate from the Senkaku/Diaoyu disputes in the East China Sea. Essentially, Tokyo views the disputes in the South China Sea as a gauge of the potential of Chinese assertiveness in pursuing its offshore claims. What happens in the South China Sea could set a precedent for the East China Sea-so Japan is anxious to avoid China's direct employment of force. Indeed, whenever Abe stresses adherence to the rule of law, the South and East China Seas are often mentioned together.

\section{EMERGING AMERICAN AND JAPANESE STRATEGIES IN THE SOUTH CHINA SEA}

The involvement of the U.S. and Japan in the South China Sea has progressed along with their changing concerns on the threats to their national interests. The evolving strategies of Washington and Tokyo reflect the changing security and geopolitical dynamics of maritime Southeast Asia since the Cold War. From sealane navigational safety and security, mostly focused on the Malacca Strait during the Cold War Era, to the most recent hegemonic threats from the rising China, the U.S. and Japan's more vocal and active South China Sea policies show that they provide a premium on maritime security and more broadly on the Western- 
constructed liberal order in East Asia. For Japan, this confirms earlier studies on its foreign policy that while it has its own interests, it remains to be an "Asian member of the West" (Pressello 2012).

In recent years, American and Japanese strategies have emerged reflecting three main approaches: internationalization, legalization, and deterrence. These are balancing acts by both outside powers to protect their interests and prevent China from controlling and dominating maritime Southeast Asia. These security strategies confirm that the two countries have been employing both soft and hard balancing, simultaneously in the South China Sea.

\section{Internationalization}

It must be re-emphasized that Beijing is opposed to the disputes' internationalization and maintains that they must be handled exclusively through bilateral negotiations and consultations with direct claimants. Such view is widely held in China, even among those in the military. The People's Liberation Army (PLA) Daily in 2011 published an op-ed echoing statements from the Chinese Foreign Ministry. "China firmly opposes attempts to internationalize the South China Sea issue, which should only be resolved bilaterally through friendly consultations between parties involved" (Xinhua 2011).

China's emphasis on bilateralism in the handling of territorial and maritime disputes does not sit well among claimant countries. Hanoi and Manila in particular are worried that China's sheer size alone would put them at a disadvantage. For Manila, many of the disputed features are multilateral in nature, involving more than two countries directly. Manila also believes that the issues are so large, concern the global maritime order, that they should be negotiated upon more than two countries. The Philippines is also mindful of its previous diplomatic experiences. Foreign Affairs Secretary Albert Del Rosario said, "We are for bilateral talks, but we ran into a dead end in terms of using that approach. In the case of Scarborough Shoal, we had over 50 bilateral engagements with them and that did not work because in every bilateral meeting you have with China, unfortunately, [leads to their saying] to you, 'We have indisputable sovereignty over the entire South China Sea"' (The Manila Times 2015).

The Philippines and Vietnam have therefore led efforts in internationalizing the disputes. They do this by making sure the South China Sea issues are discussed in all possible multilateral platforms such as ASEAN, ASEAN Regional Forum and East Asia Summit, among others. They have also been putting the issue on their bilateral agenda with other countries, particularly with great powers. But apart from direct claimant countries, the U.S. and Japan have been as active in "internationalizing" the South China Sea disputes for quite some time. Both Washington and Tokyo are internationalizing the South China Sea disputes through 
their own bilateral and multilateral security engagements in the region. They do this by linking the disputes to wider international concerns such as freedom of navigation, access to global commons and respect for international law, as well as by connecting the disputes broadly to the peace and stability of the East Asian region.

For the U.S., internationalizing the South China Sea disputes has recently been quite apparent. It all became clear and more explicit when, as noted above, during the 2010 ARF in Hanoi, then-Secretary of State Clinton declared that the South China Sea was in the U.S. national interests emphasizing the maintenance of "freedom of navigation and unimpeded lawful commerce" as well as Washington's opposition to any use of coercion and force to settle disputes. This first obvious move on the part of the U.S. to soft-balance China by internationalizing the South China Sea disputes drew rebuke from Beijing. But it was seen as a signal by littoral states opposed to China's nine-dash line map. It must be noted that prior to Clinton's meeting with ARF participants that year, her Chinese counterpart Yang Jeichi had the same opportunity. Only Manila's diplomat attempted to bring up the South China Sea issue. When it became apparent that Clinton would take a more concrete stance, 11 other ARF participants issued statements on the South China Sea issue (Chang 2010). Since then, most if not all of America's diplomatic engagements related to maritime Southeast Asia have been efforts to link the South China Sea disputes to wider international concerns, particularly freedom of navigation, respect for international law and Washington's opposition to any use of coercion and force. For instance, President Barack Obama's Asia tour in 2014 that made him visit Japan, South Korea, the Philippines and Malaysia, was largely dominated by regional maritime disputes. In Kuala Lumpur, his joint statement with Malaysian Prime Minister Najib Razak touched upon "recent developments in the South China Sea and affirmed the importance of safeguarding maritime security and ensuring freedom of navigation and overflight throughout the region, including critical waterways in the South China Sea" (The White House 2014a). Likewise in Manila, Obama praised the Philippines' decision to seek international arbitration.

Many of Obama's own bilateral engagements in Asia and the Pacific have recently included statements touching on the South China Sea. For instance, his joint-statement with Indian Prime Minister Narendra Modi released after their first bilateral meeting on September 30, 2014 stated: "The leaders expressed concern about rising tensions over maritime territorial disputes, and affirmed the importance of safeguarding maritime security and ensuring freedom of navigation and overflight throughout the region, especially in the South China Sea ...," (The White House 2014b).

Meanwhile, Japan believes that the South China Sea issue directly involves "the peace and stability of the region and is a common concern of the international 
community as a whole since the issue influences the international maritime order" (Ministry of Foreign Affairs of Japan 2014a). Hence, apart from direct claimants and the U.S., Japan has also been playing a critical role in internationalizing the South China Sea disputes. For instance, in early 2014, it urged the Group of 7 (G-7) to issue a statement of concern. "We are deeply concerned by tensions in the East and South China Seas. We oppose any unilateral attempt by any party to assert its territorial or maritime claims through the use of intimidation, coercion or force," said the G7 leaders in a statement during their June 2014 Summit in Brussels that was widely attributed to Prime Minister Abe's request (Reuters 2014).

Joint statements by Prime Minister Abe and his counterparts in ASEAN, India, the UK, Germany, and France, among other countries also mention a similar general refrain-freedom of navigation and over-flight, unimpeded lawful commerce and respect for international law. In some countries, Abe's joint statements with his counterparts are more direct, such as with former Prime Minister Tony Abbott of Australia. "They opposed any unilateral attempt to alter the status quo in the East and South China Seas by the use of force or coercion. Emphasizing the need for disputes and issues to be settled by peaceful means, they called on all parties concerned to refrain from actions that could increase tensions, to clarify and pursue all claims in accordance with international law, including the United Nations Convention on the Law of the Sea, and for ASEAN and China to reach early agreement on an effective Code of Conduct in the South China Sea" (Ministry of Foreign Affairs of Japan 2014b). All of these are part of an implicit Japanese strategy of further internationalizing the South China Sea issue.

\section{Legalization}

Both Washington and Tokyo have also been soft-balancing China by pushing for legalization in the South China Sea. For instance, both outside powers want China and ASEAN to conclude a binding code of conduct in disputed domains, as well as for greater adherence to international law, particularly UNCLOS. Apparently, both of them see the potential of legal frameworks, governance mechanisms and international law to restrain China's threatening behavior.

The U.S. started to become explicit in expressing its legal views on China's nine-dash line map only in early 2014. It was when Assistant Secretary of State for East Asian and Pacific Affairs Daniel Russel asserted during a testimony before the U.S. House of Representatives Committee on Foreign Affairs that under international law, claims in the South China Sea "must be derived from land features" (U.S. Department of State 2014). He said that Beijing's use of the ninedash line to claim maritime rights not based on claimed land features "would be inconsistent with international law." He argues that China should clarify, and if necessary adjust its claim to be consistent with what UNCLOS prescribes. 
However, even prior to Russel's testimony before the American Congress, international law has always been prominent in Washington's South China Searelated statements albeit in a more general terms. For instance, a joint U.S.Philippines Declaration on the $60^{\text {th }}$ Anniversary of their treaty alliance in 2011 stressed that both countries "subscribe to a rules-based approach in resolving competing claims in maritime areas through peaceful, collaborative, multilateral, and diplomatic processes within the framework of international law" (U.S. Department of State 2011).

Similar wordings and broad reference to international law have characterized U.S. engagements in maritime Southeast Asia since 2010. It can be argued that these have encouraged Southeast Asian claimant states to use the normative power of international law to attempt to influence China's threatening behavior.

Indeed, in January 2013, Manila filed its statement of claim before a UN Court to invalidate China's nine-dash line map in the South China Sea. Moreover, in December 2014, Hanoi also filed a Statement of Interest before the UN's Permanent Court of Arbitration asking the judges to consider Vietnam's legal rights and obligations in assessing the Philippines' case against China. Hanoi's Statement of Interest also declares that UNCLOS and its tribunals have jurisdiction over what the Philippines wants settled-declare China's u-shaped nine-dash line map as invalid, among others. The legal maneuvers of direct claimants have been widely supported by Washington through statements coming from the White House, the State Department, the Defense Department and the U.S. Congress.

Likewise, on the part of Japan, it has been active in supporting legalization efforts to manage disputes in the South China Sea. During his keynote address at the 13th Shangri-La Dialogue in Singapore on May 30, 2014, Prime Minister Abe remarked, "Last year, I visited all ten ASEAN member countries, and my determination grew increasingly firm with each country I visited. This is because these visits taught me that we share common groundwork regarding our commitment to valuing the rule of law, and that we enjoy a consensus in our respect for freedom of navigation and freedom of overflight" (Ministry of Foreign Affairs of Japan 2014c). He ended his speech by stressing, "Japan for the rule of law. Asia for the rule of law. And the rule of law for all of us." Such overwhelming underscoring of the rule of law is part of Tokyo's China strategy and it wants to use the same mantra for its interests in the South China Sea. For the entire 2014, all foreign policy-related speeches of the Japanese Prime Minister, and all South China Sea-related statements coming from the Ministry of Foreign Affairs mention the importance of the rule of law. When Manila formally filed its memorial before the Arbitral Tribunal formed in The Hague to hear its case against Beijing, Japan was the second major country after the U.S. to express its support. Part of the statement says, "The Government of Japan supports the Philippines' use of procedures under the United Nations Convention on the Law of the Sea aiming at 
peaceful settlement of disputes on the basis of international law, as such an action contributes to the maintenance and enhancement of the international order in the region based on the rule of law" (Ministry of Foreign Affairs of Japan 2014a).

Likewise, when Hanoi was scrambling all its diplomatic assets to shame Beijing over its deployment of an oilrig in May 2014 within the waters considered part of the Vietnamese maritime entitlement, Tokyo again expressed its interest in the issue by underscoring the significance of the rule of law. Japanese Foreign Minister Fumio Kishida said at a press conference during the height of the oilrig crisis, "Tensions in the region have increased as a result of China unilaterally commencing excavation in an area of ocean with undefined borders, which I am deeply worried about. Furthermore, this situation can be viewed as one step in a series of unilateral and provocative maritime advances by China. I believe the Chinese side should elucidate the basis for and the details of its activities to the Vietnamese side and the international community. The peace and stability of the South China Sea is a matter of concern of the international community. I believe this is a problem that should be resolved peacefully through dialogue. Furthermore, the relevant countries are moving to create a code of conduct in connection with the South China Sea, and I by all means want to call on the countries concerned to refrain from unilateral actions such as this that heighten tension, respect international law and behave with self-restraint" (Ministry of Foreign Affairs of Japan 2014d).

Japan wants any change to the status-quo in the South China Sea, particularly on maritime entitlements and boundaries to be done so in accordance with international law. Hence, Japan has been emphasizing the importance of upholding the rule of law. This is also a venue for Tokyo to rally global public opinion against perceived Chinese assertiveness and dominating behavior on the disputed waters of East Asia.

\section{Deterrence}

Finally, the U.S. and Japan want to deter China from using force through hard-balancing. Indeed, both countries have been helping littoral states to reestablish maritime security capabilities through direct military and paramilitary assistance, as well as closer engagements.

For the U.S., the most obvious manifestation of this commitment was its decision to significantly supplement the Philippines' deterrent capability by prepositioning American troops, naval vessels, and aircraft on a rotational basis in Philippine military bases through the 10-Year Enhanced Defense Cooperation Agreement (EDCA). The deal signed in April 2014 further institutionalized the two countries' Mutual Defense Treaty. The most significant aspect of this deal is the fact that there is no limit on the number of personnel, aircraft and vessels that 
could be deployed by the U.S. in Philippine bases and the tenure is renewable from an initial ten years (Thayer 2014). In particular, Manila seems to be pushing for the deployment of U.S. military personnel and vessels in Oyster Bay, in Palawan which is facing China's nine-dash line map while American officials have earlier signified interest in returning to Subic Bay. Such an arrangement would provide the U.S. military an immediate and direct operational access to the vast South China Sea, thereby significantly undercutting China's emerging anti-access and area-denial (A2AD) capabilities. Recent joint military exercises between the U.S. and the Philippines have also focused on retaking islands and more broadly, territorial defense, a notable shift from previous defense drills that focused mainly on counter-insurgency and terrorism. While many in the Philippine left have questioned EDCA's constitutionality, the country's Supreme Court is scheduled to rule on its legality by December 2015 .

Washington is also deepening its security engagements with other direct claimant states-Vietnam and Malaysia. In 2011, the U.S. and Vietnam signed a memorandum of understanding on defense cooperation. The Vietnamese Navy and Coast Guards now have institutionalized cooperative mechanisms with their American counterparts. Recently, the U.S. also lifted its sweeping arms embargo against Hanoi, making available maritime assets necessary for Vietnam to defend the status quo in the South China Sea. In April 2014, President Obama discussed with Malaysian Prime Minister Razak ways through which the U.S. could support the development of Malaysia's maritime enforcement capacity through the provision of training, equipment and expertise.

All of these efforts are geared towards increasing the deterrent capabilities, as well as maritime law enforcement capacities of littoral states in the South China Sea, enabling them to counter Chinese maneuvers and maintain the status quo. The U.S. hopes that these efforts will add up in the long-run and dissuade China from using force due to increased practical cost, apart from expected reputational losses.

Because of Japan's close proximity to China and the South China Sea, and its own disputes with Beijing in the East China Sea, it too has an interest in maintaining the status-quo and regional stability by deterring China's possible use of force. However, rallying global public opinion by simply internationalizing the disputes and strengthening the rule of law narrative in East Asia may prove to be insufficient in maintaining the status quo in the long run, particularly if the balance of power in maritime Southeast Asia continues to tilt heavily on the side of the Chinese. Such power imbalance, characterized by an extensive gap in military power, maritime domain awareness, and maritime law-enforcement capacity between China and the Southeast Asian claimant states, may decrease the cost for Beijing to use threats or direct force in order to achieve fait accompli.

To address this concern, Japan has been nurturing its own strategic partnerships with several countries in ASEAN, particularly with major claimant states, Vietnam 
and the Philippines. These strategic partnerships serve as the framework through which Japan could enhance the deterrent capabilities of the claimant states. For instance, it wants to support the upgrading of the Philippines' maritime capability. The Japan-Philippines Dialogue on Maritime and Oceanic Affairs held for the first time on September 9, 2011 demonstrates the importance of the South China Sea to their strategic partnership. Part of a post-summit official statement that confirms the upgrading of the two countries relationship into strategic partnership on September 27, 2011 states, "The two leaders confirmed that the South China Sea is vital, as it connects the world and the Asia Pacific region, and that peace and stability therein is of common interest to the international community. As leaders of countries sharing sea lines of communication, they also confirmed that freedom of navigation, unimpeded commerce, and compliance with established international law including the UNCLOS and the peaceful settlement of disputes serve the interests of the two countries and the whole region. They shared the recognition that these same interests should also be advanced and protected in the South China Sea" (Ministry of Foreign Affairs of Japan 2011).

More concretely, Tokyo is providing Manila with ten brand new Coast Guard vessels through Overseas Development Assistance (ODA). Tokyo hopes that the ten new multi-role Coast Guard vessels, each costing 1 billion yen (US\$ 8.1 million), would help Manila maintain the status quo in the South China Sea. In addition, Tokyo is also exploring other means to support the Philippines' military capability, which in the future could include assistance in the acquisition of defense hardware (Sato 2013). The SDF has also begun conducting training exercises with the Armed Forces of the Philippines (AFP). One such instance happened on June 22-26, 2015. Media reports indicated that during that exercise, Japan's P3-C Orion reconnaissance aircraft, with three Filipino crew members on board, accompanied by a smaller Islander patrol plane of the Philippine Navy flew over the edge of the Reed Bank, a submerged feature disputed by China in the Spratlys.

Japan has a similar coast-guard arrangement with Hanoi, though at a smaller scale. China's deployment of an oil rig in May 2014 made Vietnam's needs more urgent and it had asked Japan for second-hand Coast Guard vessels. An official statement from the Foreign Ministry in Tokyo during Vietnam's oilrig crisis mentioned that Japan was giving Viet Nam a total of six used patrol boats worth 500 million yen (Approx. US\$ 4 million). By the third quarter of 2015, two had already been turned over to Hanoi. Japanese Foreign Minister Fumio Kishida was quoted by international media as saying, "International security is getting more complicated ... prosperity only comes with stability in the South China Sea and the East China Sea. I hope this equipment will strengthen the ability of Vietnam's coastal enforcement authorities" (Panda 2014). Tokyo has also been involved in training Filipino and Vietnamese Coast Guard personnel. In fiscal year 2013, it 
allotted a budget of 2.5 billion yen for such purpose.

Moreover, these strategic partnerships were not limited to South China Sea claimant states. Japan knows that other ASEAN states, particularly the smaller ones could derail the internationalization of the South China Sea disputes during ASEAN Summits. In December 2014, Japan upgraded its relationship with Cambodia into a strategic partnership. A statement from the Japanese Foreign Ministry at the conclusion of the Japan-Cambodia Summit on December 15, 2013 stated, "The two leaders, upon the proposal from Cambodia during Prime Minister Abe's visit last month, decided to upgrade the bilateral relations from an existing 'new partnership' to a 'strategic partnership' and also to coordinate and cooperate more closely on regional and international issues. They also shared the view that the signing of the memorandum of cooperation on defense cooperation and exchanges would serve as a great showcase of their strategic partnership .... The two leaders exchanged views on regional and international situations, including the issue of the South China Sea" (Ministry of Foreign Affairs of Japan 2013). It must be noted that Cambodia represented the wishes of Beijing during the 2012 ASEAN Summit's discussion on the South China Sea issue (Thayer 2012). Phnom Penh's pro-Beijing positions were reportedly opposed by Hanoi and Manila leading to a failure to issue a joint communiqué immediately after the summit. By establishing a strategic partnership with Cambodia, Japan is hoping to dilute Chinese influence in ASEAN's future South China Sea discussions. It must be noted that prior to 2009, Japan's only strategic partner in Southeast Asia was Indonesia in which the primary security-related motivation was the continued freedom of navigation, safety and unimpeded commerce in the Strait of Malacca.

All of these demonstrate that apart from soft-balancing through internationalization and legalization, the U.S. and Japan have also been hard-balancing Beijing in the South China Sea through coalition building and indirectly, military means. Considering Japan's constitutional restrictions on its defense policies, the country's effort to upgrade the security capabilities of littoral states in Southeast Asia is significant. Meanwhile, the U.S. is obviously increasing its military presence in the Western Pacific through its rebalancing to Asia. EDCA would allow Washington to build up military forces within the direct vicinity of the South China Sea.

These three-internationalization, legalization and deterrence-have been the primary modalities for the U.S. and Japan to protect their own interests in the South China Sea and prevent China from controlling the important sea-lane and critical choke point, in particular and from dominating maritime East Asia, in general. Soft-balancing such as internationalization and legalization and hard balancing efforts were perceived as complementing each other by the Japanese and Americans against Chinese advances in East Asia's maritime commons. They both serve as tools to restrain China's ambitions in the South China Sea. However, it remains to be seen if these emerging strategies will prove to be successful. 


\section{CONCLUSION}

The more active and vocal involvement of the U.S. and Japan in the South China Sea disputes in recent years can be explained mainly by the interplay of their own interests rooted on economic, security, and geopolitical considerations vis-à-vis the perceived assertiveness and increasing status of the rising China in maritime Southeast Asia. In other words, American and Japanese interests in the South China Sea underpin their security strategies of internationalization, legalization and deterrence. The more they perceive China-its behaviors in disputed domains and status as an emerging super power-as a threat to those interests, the more they are likely to employ soft and hard balancing to frustrate Beijing.

Indeed, the U.S. and Japan in recent years have been employing albeit implicitly, the three pronged strategy, involving internationalization, legalization and deterrence. The first two can be classified as non-military or soft-balancing, while the third is balancing through military and paramilitary means. This proves that for Washington and Tokyo, hard and soft balancing are complements. The internationalization and legalization efforts provide moral ascendancy to their opposition to China's South China Sea policies and behaviors, which complement their efforts to hard balance Beijing.

By internationalizing the disputes, the U.S. and Japan could prevent China from dominating the discussions toward settlements and could make sure that their interests were not jeopardized in the process. Also, by connecting the disputes to wider international concerns such as the free flow of commercial vessels, which has not been jeopardized by China's actions thus far, both countries could legitimize their active involvement in the South China Sea.

By constantly advocating the peaceful settlement of disputes through adherence to international law, and by encouraging de-escalating mechanisms, such as the long delayed Code of Conduct, Washington and Tokyo hope to further protect their interests in the South China Sea. The rule of law narrative in East Asia may deter Beijing from out-rightly using force to change status quos to its favor. Any direct employment of force by Beijing against Vietnam and the Philippines could potentially leave the U.S. and Japan's South China Sea activities at the mercy of Chinese maritime law-enforcement authorities.

Finally, to complement internationalization and their advocacy for the rule of law, both Washington and Tokyo have been endeavoring to influence China's appetite for the use of coercion and force through direct military assistance and deepening of security engagements with ASEAN as a whole and with Southeast Asian-claimant states individually. By endeavoring to increase the maritime security and law-enforcement capacities of littoral states, Washington and Tokyo hope to dilute China's rising capabilities and superiority to project its growing maritime and air power in the South China Sea. For the U.S., its efforts to deter China have 
further expanded from merely boosting the defense capabilities of littoral states, but also to being present physically in maritime Southeast Asia through various security cooperation mechanisms with Vietnam and Malaysia, and the Enhanced Defense Cooperation Agreement with its treaty-ally, the Philippines. The U.S. is also doing this by sailing naval vessels through select waters of the Spratlys, effectively not recognizing China's territorial water entitlement claim around some of its artificial islands built on top of submerged features and low-tide elevations.

Overall, this paper demonstrates two important theoretical considerations. First, soft and hard balancing are not mutually exclusive and are not necessarily employed by states separately as substitutes. As revealed by how the U.S. and Japan have been employing them against China in the South China Sea, hard and soft balancing as security strategies, could be used simultaneously as complements. For instance, while the U.S. continues to frustrate China's South China Sea narrative and claims by internationalizing and legalizing the disputes, Washington is also increasing its military presence in the South China Sea through initiatives like EDCA and freedom of navigation operations within the waters of the Spratlys. Moreover, in contrast to research dealing with soft-balancing, the cases mentioned in this paper reveal that soft-balancing can also be employed by a militarily superior state against an inferior one. The U.S. is clearly more powerful than China in terms of military capabilities, at least for the time being. Second, the security strategies of the U.S. and Japan in the South China Sea are far from being altruistic. They do not attempt to balance China for the purpose of helping smaller states resist great-power threats or for preserving the rule of law and strengthening institutions in the South China Sea. Their attempts to balance China have been primarily motivated by their own national interests in the South China Sea as detailed in this paper.

In the years ahead, both the U.S. and Japan are likely to continue to internationalize the South China Sea disputes, to push for legal mechanisms for both management of disputes and resolution of overlapping claims, and to deter China through direct engagements with Southeast Asian littoral states, and even increased presence in disputed domains. Whether these strategies are enough to restrain China and maintain the status quo or not remains to be seen. In early 2016, the Permanent Court of Arbitration in The Hague is expected to issue an award on the case the Philippines filed against China, after ruling in November 2015 that it had jurisdiction on the case. Moreover, China's reclamation and construction on disputed reefs are continuing, with suspicion that these will be converted primarily into military installations, and are a prelude to declaring an Air Defense Identification Zone (ADIZ), among other possible power projection activities. These things, among other factors, will significantly shape how the U.S. and Japan would continue to approach their interests and strategies in the South China Sea. 


\section{REFERENCES}

Bonnet, Francois-Xavier. 2012. Geopolitics of Scarborough Shoal. Discussion Papers, IRASEC 14.

Bower, Ernest Z. 2012. China Reveals Its Hand on ASEAN in Phnom Penh. Center for Strategic and International Studies. July 20. http://csis.org/publi cation/china-reveals-its-hand-asean-phnom-penh (accessed December 15, 2014).

Bradsher, Keith. 2010. China Is Blocking Minerals, Executives Say. The New York Times, September 24. B1.

Buszynski, Leszek and Iskandar Sazlan. 2007. Maritime Claims and Energy Cooperation in the South China Sea. Contemporary Southeast Asia 29(1): 143171.

Chang, Gordon. 2010. Hillary Clinton Changes America's China Policy. Forbes. July 28. http://www.forbes.com/2010/07/28/china-beijing-asia-hillary-clintonopinions-columnists-gordon-g-chang.html (accessed January 10, 2015).

Chu Shulong. 2014. China's View on U.S. Policy in the South China Sea. In Perspectives on the South China Sea, edited by Murray Hiebert, Phuong Nguyen and Gregory Poling, 17-18. Lanham, MD: Rowman and Littlefield.

Dyer, Geoff and Demetri Sevastopulo. 2014. US strategists face dilemma over Beijing claim in South China Sea. Financial Times. July 9. http://www.ft. com/cms/s/0/b2176dea-0732-11e4-81c6-00144feab7de.html\#axzz3rFo5yiMw (accessed Novermber 12, 2015).

Fravel, M. Taylor. 2014. Hainan's New Fishing Rules: A Preliminary Analysis. The Diplomat. January 10. http://thediplomat.com/2014/01/hainans-new-fishi ng-rules-a-preliminary-analysis/(accessed October 20, 2014).

Fuchs, Michael. 2014. Remarks at the Fourth Annual South China Sea Conference. CSIS, Washington, DC, July 11. http://www.state.gov/p/eap/rls/rm/2014/07/ 229129.htm(accessed Novermber 8, 2015).

Haddick, Robert. 2012. Salami Slicing in the South China Sea. Foreign Policy. August 3. http://foreignpolicy.com/2012/08/03/salami-slicing-in-the-southchina-sea/(accessed October 10, 2015)

Hayton, Bill. 2014. The South China Sea The Struggle for Power in Asia. New Haven and London: Yale University Press.

Hong, Nong. 2012. UNCLOS and Ocean Dispute Settlement: Law and Politics in the South China Sea. New York: Routledge.

Japan External Trade Organization. Japan's International Trade in Goods 2013. 2014. http:/www.jetro.go.jp/en/reports/statistics/data/gaikyo201312e.xls(accessed November 17, 2014).

Kaplan, Brad. 2013. Rich Region, Strong States: The Political Economy of Security in Asia. Policy Brief 2013-7, University of California Institute on Global 
Conflict and Cooperation. http://igcc.ucsd.edu/assets/001/504657.pdf (accessed January 10, 2015).

Kaplan, Robert. 2014. Asia's Cauldron: The South China Sea and the End of a Stable Pacific. New York: Random House.

Kim, Hyun-soo. 1994. The 1992 Chinese Territorial Sea Law in the Light of the UN Convention. The International and Comparative Law Quarterly 43(4): 894-904.

Le Mière, Christian and Sarah Raine. 2013. Regional Disorder: The South China Sea Disputes. London: Routledge.

Manicom, James. 2014. China and American Seapower in East Asia: Is Accommodation Possible?. Journal of Strategic Studies 37(3): 345-371.

Mearsheimer, John J. 2014. The Tragedy of Great Power Politics. New York: W. W. Norton and Company.

Ministry of Foreign Affairs of Japan. 2011. Japan-Philippines Joint Statement on the Comprehensive Promotion of the 'Strategic Partnership' between Neighboring Countries Connected by Special Bonds of Friendship. September 27. http://www.mofa.go.jp/announce/pm/noda/joint_statement110927.html (accessed December 11, 2014).

Ministry of Foreign Affairs of Japan. 2013. Joint Statement between Japan and the Kingdom of Cambodia. November 17. http://www.mofa.go.jp/mofaj/files/000 019646.pdf (accessed December 12, 2014).

Ministry of Foreign Affairs of Japan. 2014a. Statement by the Press Secretary on an Issue concerning the South China Sea. March 31. http://www.mofa.go. jp/press/release/press4e_000257.html (accessed December 1, 2014).

Ministry of Foreign Affairs of Japan. 2014b. Prime Minister Abbott and Prime Minister Abe Joint Statement: Special Strategic Partnership for the $21^{\text {st }}$ Century. July. http://www.mofa.go.jp/files/000044640.pdf (accessed December 10, 2014).

Ministry of Foreign Affairs of Japan. 2014c. Keynote Address by H.E. Mr. Shinzo Abe, Prime Minister of Japan at the 13th IISS Asian Security Summit, Shangri-La Dialogue, May 30. http://www.mofa.go.jp/fp/nsp/page18e_0000 87.html(accessed March 1, 2015).

Ministry of Foreign Affairs of Japan. 2014d. Press Conference by Foreign Minister Fumio Kishida. May 9. http://www.mofa.go.jp/press/kaiken/kaiken4e_ 000068.html (accessed December 5, 2014).

Ministry of Foreign Affairs of Japan. 1997. The Guidelines for Japan-US Defense Cooperation. http://www.mofa.go.jp/region/n-america/us/security/guideline2. html (accessed January 15, 2015).

Ministry of Internal Affairs and Communications. 2014. Statistics Bureau. Imports of Crude Oil by Region and Country. http://www.stat.go.jp/data/nenkan/zuh you/y1008000.xls (accessed November 5, 2014). 
Panda, Ankit. 2014. Vietnam to Acquire Japanese Maritime Surveillance Ships. The Diplomat, August 2. http://thediplomat.com/2014/08/vietnam-to-acquirejapanese-maritime-surveillance-ships/(accessed December 14, 2014).

Pape, Robert. 2005. Soft Balancing against the United States. International Security 30(1): 7-45.

Paul, T. V. 2005. Soft Balancing in the Age of U.S. Primacy. International Security 30(1): 46-71.

Pedrozo, Raul. 2009. Close Encounters at Sea. Naval War College Review 62(3): 101-111.

Pressello, Andrea. 2013. Japan's Twin-Track Diplomacy during the Cambodian Conflict, 1979-1984: A 'Member of the West' Pursuing an Independent Foreign Policy. Asian Studies Review 37(1): 42-61.

Raine, Sarah and Christian Le Mière. 2013. Regional Disorder: The South China Sea Disputes. London: Routledge.

Reuters. 2014. G7 'Deeply Concerned' at Tensions in East, South China Seas. June 4.

Rosenberg, David. 2010. Governing the South China Sea: From Freedom of the Seas to Ocean Enclosure Movements. Harvard Asia Quarterly 12(3): 4-12.

Saltzman, Ilai Z. 2012. Soft Balancing as Foreign Policy: Assessing American Strategy toward Japan in the Interwar Period. Foreign Policy Analysis 8(2): 131-150.

Sato, Yoichiro. 2007. Southeast Asian Receptiveness to Japanese Maritime Security Cooperation. Asia Pacific Center for Security Studies. September. http://apcss. org/Publications/Maritime\%20security\%20cooperation\%20Japan-SE\%20As ia\%20Sato.pdf (accessed November 11, 2015).

Sato, Yoichiro. 2013. Japan Aid to the Philippines a Warning to China. East Asia Forum. August 29.

Storey, Ian James. 1999. Creeping Assertiveness: China, the Philippines and the South China Sea Dispute. Contemporary Southeast Asia 21(1): 95-118.

Storey, Ian James. 2013. Japan's Maritime Security Interests in Southeast Asia and the South China Sea Dispute. Political Science 65(2): 135-156.

Thayer, Carl. 2012. ASEAN's Code of Conduct in the South China Sea: A Litmus Test for Community-Building?. The Asia-Pacific Journal 10, 34(4): 1-23.

Thayer, Carl. 2014. Analyzing the US-Philippines Enhanced Defense Cooperation Agreement. The Diplomat. May 2. http://thediplomat.com/2014/05/analyzing -the-us-philippines-enhanced-defense-cooperation-agreement/(accessed December 10, 2014).

The Manila Times. 2015. Talks Reach Dead End. April 16. http://www.manila times.net/talks-reach-dead-end/176045/(accessed September 5, 2015).

The White House. 2014a. Office of the Press Secretary. Joint Statement By President Obama And Prime Minister Najib Of Malaysia. April 27. https://www.white 
house.gov/the-press-office/2014/04/27/joint-statement-president-obama-andprime-minister-najib-malaysia (accessed December 15, 2014).

The White House. 2014b. Office of the Press Secretary. U.S.-India Joint Statement. September 30. https://www.whitehouse.gov/the-press-office/2014/04/27/joint -statement-president-obama-and-prime-minister-najib-malaysia (accessed December 15, 2014).

UN News Centre. 2014. At UN Assembly, Philippines Decries Expansionist Territorial Claims in Region. September 29. http://www.un.org/apps/news/story. asp?NewsID=48945\#.VQ1kHEYyFNI (accessed October 28, 2015).

United States Senate. 2015. Letter to Secretary Carter and Secretary Kerry on Chinese Maritime Strategy. http://www.armed-services.senate.gov/letter-tosecretary-carter-and-secretary-kerry-on-chinese-maritime-strategy (accessed March 21, 2015).

U.S. Department of State. 2010. Press Remarks by Secretary Hillary Clinton. 23 July. http://m.state.gov/md145095.htm (accessed December 10, 2014).

U.S. Department of State. 2011. Manila Declaration on U.S.-Philippine Alliance. November 16. http://translations.state.gov/st/english/texttrans/2011/11/20111 116141458su0.2878338.html\#axzz3V2DlLUrk (accessed December 10, 2014).

U.S. Department of State. 2014. Maritime Disputes in East Asia. Testimony by Daniel R. Russel, Assistant Secretary, Bureau of East Asian and Pacific Affairs, Before the House Committee on Foreign Affairs Subcommittee on Asia and the Pacific. February 5. http://www.state.gov/p/eap/rls/rm/2014/02/ 221293.htm (accessed December 10, 2014).

US Department of State. n.d. Maritime Security and Navigation. http://www. state.gov/e/oes/ocns/opa/maritimesecurity/(accessed March 1, 2015).

Valencia, Mark, Jon M. Van Dyke and Noel A. Ludiwg. 1999. Sharing the Resources of the South China Sea. Honolulu: University of Hawaii Press.

Vertzberger, Yaacov Y. I. 1984. Coastal States, Regional Powers, Superpowers and the Malacca-Singapore Straits. Berkeley, CA: University of California 9. Vuving, Alexander. 2014. Vietnam, the US, and Japan in the South China Sea. The Diplomat, November 26.

Xinhua. 2011. China opposes attempts to internationalize South China Sea issue: military newspaper. June 15 . http://eng.chinamil.com.cn/news-channels/chinamilitary-news/2011-06/15/content_4452206.htm (accessed January 1, 2015).

$\mathrm{Xu}$, Beina. 2014. South China Sea Tensions. Council on Foreign Relations. www. cfr.org/china/south-china-sea-tensions/p29790 (accessed February 14, 2015).

Zhang, Hang. 2001. Culture and Apology: The Hainan Island Incident. World Englishes 20(3): 383-391. 